\title{
Preimplantation-embryo-specific Cell-cycle Regulation is Attributable to a Low Expression of Retinoblastoma Protein Rather Than Its Phosphorylation
}

\author{
Asuka EGASHIRA', Kiyoshi KANO ${ }^{1)}$ and Kunihiko NAITO') \\ 1) Laboratory of Applied Genetics, Graduate School of Agriculture and Life Sciences, University of Tokyo, Tokyo 113-8657, \\ Japan
}

\begin{abstract}
Mammalian preimplantation embryos enter the S phase immediately after the end of the $M$ phase; their cell cycle lacks a substantial G1 phase. Previously, we suggested that the absence of the G1 phase was attributable to a loss of retinoblastoma protein $(\mathrm{RB})$ function, which is required for suppression of $S$ phase entrance and that this loss of RB function in turn was attributable to the low RB expression level during preimplantation development in mouse embryos. The present study aimed to examine whether or not RB inhibition by CDK4/6-cyclin D-dependent phosphorylation is involved in the loss of RB function in preimplantation mouse embryos by the expression of p16 ${ }^{\mathrm{INK} 4 \mathrm{a}}$, a potent endogenous inhibitor of CDK4/6-cyclin D. First, the decrease in RB expression between the four-cell and morula stages was confirmed in in vivo-derived mouse embryos. We then examined the efficiency of the p16 ${ }^{\mathrm{INK} 4 \mathrm{a}}$ expression vector in inhibiting RB phosphorylation and cell cycle progression using NIH-3T3 cells and obtained gradual $\mathrm{RB}$ dephosphorylation and a significantly lower proliferation rate in p16 ${ }^{\mathrm{INK} 4 \mathrm{a}}$-transfected cells than in control cells. This indicated the successful p16 ${ }^{\mathrm{INK} 4 \mathrm{a}}$ effects on cell-cycle progression by the vector used. On the other hand, the development rate of mouse embryos injected with the p16 ${ }^{\mathrm{INK} 4 \mathrm{a}}$ expression vector was the same as that of the control embryos, although $\mathrm{p} 16^{\mathrm{INK} 4 \mathrm{a}}$ expression was detected at mRNA and protein levels in the former group but not in the control group. These results suggest that RB phosphorylation is not involved in RB dysfunction or in the lack of a G1 phase in mouse embryos and that the decrease in RB expression is important for preimplantation-embryo-specific cellcycle regulation. Moreover, the present study indicates the similarity between preimplantation embryos and cancer cells, which p16 ${ }^{\mathrm{INK} 4 \mathrm{a}}$ expression does not arrest at the G1 phase.
\end{abstract}

Key words: Mouse embryo, p16 ${ }^{\mathrm{INK} 4 \mathrm{a}}$, Retinoblastoma protein

(J. Reprod. Dev. 57: 492-499, 2011)

T he cell cycle of a mammalian preimplantation embryo substantially lacks a G1 phase; the embryo enters the S phase immediately after the end of the $\mathrm{M}$ phase [1-3]. This substantive absence of the G1 phase would be related to the characteristics of early embryo cleavage, such as a shortened cell cycle, mitogen independence and a lack of embryo growth.

In somatic cells, the transcription of DNA replication factors is necessary for progression to the $\mathrm{S}$ phase, and inhibition of this transcription protects cells from deregulated proliferation [4-6]. Retinoblastoma protein (RB), a well-known tumor-suppressor gene product, plays principal roles in this transcriptive inhibition. During the G1 phase, RB binds to and represses E2F, a transcriptional regulator, which can transactivate genes that are important for $\mathrm{S}$ phase entry [7, 8]. When RB is inactivated by phosphorylation by the CDK4/6-cyclin D complex [9, 10], the genes required for the G1/S transition are highly transcribed by activated E2F, and the cells enter the S phase (see schematic diagram in Fig. 4) [4, 5]. Therefore, RB dysfunction should result in continuous E2F activation and a disordered entrance into the $\mathrm{S}$ phase.

We previously found that RB expression was downregulated

Received: November 8, 2010

Accepted: March 30, 2011

Published online in J-STAGE: April 26, 2011

(C)2011 by the Society for Reproduction and Development

Correspondence: K Naito (e-mail: aknaito@mail.ecc.u-tokyo.ac.jp) between the four-cell and morula stages in early mouse embryos [11]. We also showed that RB overexpression induced the G1 phase in early mouse embryos, but only after the four-cell stage, and suggested that the low RB level caused the absence of the G1 phase after degradation of maternal factors [11]. However, Xie et al. [12] reported later that RB is present in a phosphorylated form during preimplantation development in mouse embryos and that the RB inactivation by phosphorylation, but not the low RB level, might be attributable to the preimplantation-embryo-specific absence of the G1-phase. These authors advocated the presence of faint signals of phosphorylated RB in their immunocytochemical experiments, although marked decreases of $R B$ mRNA and RB protein between the four-cell and morula stages in early mouse embryos were also detected in their experiments [12]. According to their notion, the G1 phase should appear in early mouse embryos after block of RB phosphorylation and continuous RB activation.

In the present study, we attempted to inhibit RB phosphorylation and examined whether or not G1 arrest was induced in early mouse embryos. The INK4 family inhibits RB phosphorylation by binding with CDK4/6 and prevents CDK4/6-cyclin D complex formation $[13,14]$. The expression of $\mathrm{p} 16^{\mathrm{INK} 4 \mathrm{a}}$, a member of the INK4 family, in cultured cells results in RB dephosphorylation and cell-cycle arrest in the G1 phase [15]. Normal cells express very little $\mathrm{p} 16^{\mathrm{INK} 4 \mathrm{a}}$, and its high expression is observed only under restricted conditions, such as in senescent cells [16]. The G1-arrest 
ability of $\mathrm{p} 16^{\mathrm{INK} 4 \mathrm{a}}$ is so extensive that cancer cells lacking RB expression are the only cells that are not arrested at the G1 phase by p16 $6^{\text {INK4a }}$ overexpression $[17,18]$. This should provide potent proof of the similarity of cell-cycle regulation in early embryos and cancer cells, if early embryos do not arrest at the G1 phase after $\mathrm{p} 16^{\text {INK4a }}$ overexpression. Although there may be great biological importance to revealing the similarities between early embryos and cancer cells, p16 $6^{\text {INK4a }}$ overexpression has never been examined in mammalian preimplantation embryos. Therefore, we employed p16 $6^{\text {INK4a }}$ overexpression for inhibition of RB phosphorylation. Before that, RB downregulation during preimplantation development was confirmed first in in vivo-derived mouse embryos in order to eliminate the possibility that the previous results from in vitro fertilized and in vitro cultured embryos were artifacts [11]. Then the efficiency with which the $\mathrm{p} 16^{\text {INK4a }}$ expression vector inhibited RB phosphorylation and induced the G1 arrest were examined in cultured cells because the effects of expressed $\mathrm{p} 16^{\text {INK4a }}$ on RB phosphorylation could not be confirmed in embryos on account of the low RB and Cyclin D expression levels. Finally, p $16^{\text {INK4a }}$ was overexpressed in preimplantation mouse embryos by pronuclear microinjection of the expression vector, and the developmental states were examined.

\section{Materials and Methods}

\section{Collection of in vivo oocytes and embryos}

In vivo oocytes and embryos were collected from 7- to 10-weekold female ICR mice (SLC Japan, Tokyo, Japan). The female mice were superovulated by intraperitoneal injection of 7.5 IU pregnant mare serum gonadotropin (ASKA Pharmaceutical, Tokyo, Japan) followed $48 \mathrm{~h}$ later by $7.5 \mathrm{IU}$ human chorionic gonadotropin (hCG; ASKA Pharmaceutical) and mated overnight with ICR mice (SLC Japan) that were more than 10 weeks old. At 24, 48, 60 and $72 \mathrm{~h}$ after hCG injection, 1-, 2-, 4- and 8-16-cell embryos, respectively, were collected by oviduct flushing with $0.1 \%$ polyvinylpyrrolidone (PVP; Sigma-Aldrich, St. Louis, MO, USA) containing saline (PVP-saline). Morulae and blastocysts were collected by uterus flushing with PVP-saline at 84 and $96 \mathrm{~h}$ after hCG injection, respectively. Oocytes were collected $16 \mathrm{~h}$ after hCG injection from the ampullae of the oviducts without mating, and cumulus cells were removed by treatment with hyaluronidase (type IV; SigmaAldrich) and gentle pipetting.

\section{In vitro fertilization and embryo culture}

Oocytes were collected from 7- to 9-week-old female BDF1 mice (SLC Japan) superovulated as described above into HTF medium [19]. Spermatozoa were obtained from the cauda epididymis of male BDF1 mice (SLC Japan) that were more than 10 weeks old, preincubated for $1-2 \mathrm{~h}$ at $37 \mathrm{C}$ in HTF medium and added to the medium containing oocytes at a concentration of $150 \mathrm{sperm} / \mu \mathrm{l}$. The formation of pronuclei was examined at $6 \mathrm{~h}$ after insemination, and only embryos having two pronuclei were used for microinjection, as described below. The eggs were cultured for up to $96 \mathrm{~h}$ after insemination in 5\% $\mathrm{CO}_{2}$ in air at $37 \mathrm{C}$ in KSOM medium [20]. All experiments were conducted in accordance with the guide for the care and use of laboratory animals of the College of Agricul- ture, University of Tokyo.

\section{Microinjection}

The $\mathrm{p} 16^{\mathrm{INK} 4 \mathrm{a}}$ expression vector, pRC/CMV-p16 ${ }^{\mathrm{INK} 4 \mathrm{a}}$, was kindly provided by Dr J Zalvide and Dr M Wervo (University of Santiago de Compostela, Spain). Enhanced green fluorescent protein (EGFP) expression vector, pCX-EGFP, was kindly provided by Dr M Okabe and Dr J Miyazaki (Osaka University, Japan). The purified $\mathrm{p} 16^{\mathrm{INK} 4 \mathrm{a}}$ expression vector was coinjected with the EGFP expression vector into the male pronuclei of fertilized eggs at 6-9 $\mathrm{h}$ after insemination using a WR-50 microinjection apparatus (Narishige, Tokyo, Japan). Each vector was dissolved in the injection buffer (20 mM HEPES-KOH, pH 7.4, $120 \mathrm{mM} \mathrm{KCl}$ ) at a concentration of $20 \mathrm{ng} / \mu \mathrm{l}$, and the same volume was mixed. Therefore, the final concentration of each vector was $10 \mathrm{ng} / \mu \mathrm{l}$, and about $2 \mathrm{pl}$ of the DNA solution mixture was injected into each embryo. Some embryos were injected with EGFP expression vector alone (diluted to $10 \mathrm{ng} / \mu \mathrm{l}$ ). Zygotes were kept in M2 medium (M7167; SigmaAldrich) during the microinjection procedure.

\section{Examination of development stages and EGFP fluorescence}

Development stages and EGFP fluorescence were examined by fluorescence-detectable phase contrast microscopy (Diaphot 200; Nikon, Tokyo, Japan). To avoid damage by the fluorescence, EGFP expression was examined using the embryos other than 2cell stage at $24 \mathrm{~h}$ postinsemination (pi), other than 4-cell stage at 48 $\mathrm{h}$ pi, other than 8-16-cell stage at $60 \mathrm{~h}$ pi and other than morula at $72 \mathrm{~h}$ pi after their removal from culture dishes. These embryos were stopped from further culturing. Finally, all remaining embryos were examined for EGFP fluorescence at $96 \mathrm{~h}$ pi, and all EGFP-positive embryos from 24 to $96 \mathrm{~h}$ were combined and used for calculation of the development rate.

\section{Somatic cell culture and treatment}

NIH3T3 mouse fibroblasts were seeded onto $100 \mathrm{~mm}$ dishes $\left(2.5 \times 10^{5} / \mathrm{dish}\right)$ and cultured in Dulbecco's Modified Eagle’s Medium (DMEM; GIBCO BRL, Cergy, France) supplemented with $10 \%$ fetal bovine serum (FBS; JRH Biosciences, Lenexa, KS, USA). Transfection of pCX-EGFP alone or pRC/CMV-p16 $6^{\text {INK4a }}$ with pCX-EGFP was performed $24 \mathrm{~h}$ after the start of culture using the ProFection Mammalian Transfection System Calcium Phosphate (E1200; Promega, Madison, WI, USA) according to the manufacturer's instructions. Nontransfected cells were arrested in the G0/G1 phase by culturing in DMEM supplemented with $0.5 \%$ FBS for $48 \mathrm{~h}$ and then synchronized in the S phase by changing the medium to DMEM with $10 \%$ FBS and cultured for $16 \mathrm{~h}$ [21]. For proliferation experiments, transfected cells were collected at $48 \mathrm{~h}$ after transfection and reseeded in 96 -well plates $\left(1 \times 10^{3} /\right.$ well). The EGFP-positive cells were counted $24 \mathrm{~h}$ after reseeding, when most cells adhered to the plate, and changes in the count were examined every $24 \mathrm{~h}$ until $96 \mathrm{~h}$ after reseeding.

\section{Reverse transcriptase-polymerase chain reaction (RT-PCR)}

Total RNA was isolated from 50 oocytes or embryos as described previously [22]. In the case of NIH3T3 cells, $1 \mathrm{ml}$ TRIzol reagent (Gibco BRL) was added to a $100-\mathrm{mm}$ dish, and cells 
Table 1. Primer sets, cycle numbers and product sizes in RT-PCR

\begin{tabular}{|c|c|c|c|c|}
\hline Name & & Sequence & Cycle & Size (bp) \\
\hline \multirow[t]{2}{*}{$\mathrm{Rb}$} & $\mathrm{F}$ & 5'-СААСССССССАААССАСТGА-3' & 33 & 510 \\
\hline & $\mathrm{R}$ & 5'-CCAGATGTAGGGGGTCAGGA-3' & & \\
\hline \multirow[t]{2}{*}{ E2F1 } & $\mathrm{F}$ & 5'-GATCCATACССТCTGTCCCAATAGC-3' & 35 & 386 \\
\hline & $\mathrm{R}$ & 5'-ACCAAAAGTGCAGTTAGAGCCCACC-3' & & \\
\hline \multirow[t]{2}{*}{ Cyclin E } & $\mathrm{F}$ & 5'-CCCAGCAGTAAGAAGGCAGAG-3' & 35 & 287 \\
\hline & $\mathrm{R}$ & 5'-CAGCTTCTGGAGCACTCAGTG-3' & & \\
\hline \multirow[t]{2}{*}{$\mathrm{p} 16^{\mathrm{INK} 4 \mathrm{a}}$} & $\mathrm{F}$ & 5'-GTCGCAGGTTCTTGGTCAC-3' & 38 & 242 \\
\hline & $\mathrm{R}$ & 5'-TCTGCACCGTAGTTGAGCAG-3' & & \\
\hline \multirow[t]{2}{*}{ EGFP } & $\mathrm{F}$ & 5'-ACGGCAACGTGACCCTGAA-3' & 33 & 494 \\
\hline & $\mathrm{R}$ & 5'-GGGTGCTCAGGTAGTGGTT-3' & & \\
\hline \multirow[t]{2}{*}{ HPRT } & $\mathrm{F}$ & 5'-GGTGGAGATGATCTCTCAAC-3' & 33 & 320 \\
\hline & $\mathrm{R}$ & 5'-AACTTGCGCTCATCTTAGGC-3' & & \\
\hline
\end{tabular}

F: forward. R: reverse.

were collected with a scraper before RNA isolation using the same procedure as used with eggs. The RNA samples were reverse-transcribed into cDNA using SuperScript II (Gibco BRL) and random hexamers (Takara) as described previously [22]. The primer sequences and cycle numbers used for the amplification of RB, E2F1, cyclin E, p16 ${ }^{\mathrm{INK} 4 \mathrm{a}}$, EGFP and hypoxanthine phosphoribosyltransferase 1 (HPRT) are shown in Table 1 . Each cycle consisted of $30 \mathrm{sec}$ of denaturation at $94 \mathrm{C}, 30 \mathrm{sec}$ of annealing at either $56 \mathrm{C}$ (p16 ${ }^{\text {INK4a }}$, EGFP, HPRT) or 58 C (RB, E2F1, Cyclin E) and $60 \mathrm{sec}$ of extension at $72 \mathrm{C}$, followed by a final extension at $72 \mathrm{C}$ for 5 min. The PCR products were separated by electrophoresis in $2.0 \%$ agarose, stained with ethidium bromide, and photographed under ultraviolet light.

\section{Immunoblotting}

One-hundred oocytes and embryos were collected in $2.0 \mu \mathrm{l}$ of PVP-saline. NIN3T3 cells were collected with a cell scraper after being treated with $1 \mathrm{ml}$ (EGFP group) or $250 \mu \mathrm{l}$ (p16 ${ }^{\text {INK4a }}+$ EGFP group)/100-mm dish of Cytobuster Protein Extraction Reagent (Merck, Darmstadt, Germany). The samples were added with a 1/5 volume of $5 \times$ Laemmli Buffer [23], denatured immediately by boiling for $5 \mathrm{~min}$ and then stored at $-80 \mathrm{C}$ until use. The immunoblotting procedure was described previously [24]. Ten microliters of NIH3T3 samples or $2.5 \mu \mathrm{l}$ of egg samples was used for each lane in SDS-PAGE using 10\% (RB and tubulin) or 15\% (p16 ${ }^{\text {INK4a }}$ ) polyacrylamide gels. The antibodies used were as follows. The first antibodies were polyclonal anti-p16 ${ }^{\text {INK4a }}$ (sc-1207; Santa Cruz Biotechnology, Santa Cruz, CA, USA), monoclonal anti-RB (G3-245; BD Biosciences, San Jose, CA, USA), monoclonal anti-tubulin $\alpha$ (DM1A; Thermo Fisher Scientific, Fremont, CA, USA). The second antibodies were horseradish peroxidase (HRP)-conjugated anti-mouse IgG (Jackson ImmunoResearch Laboratories, West Grove, PA, USA) for RB and tubulin and HRP-conjugated antirabbit IgG (AP132P; Chemicon International, Temecula, CA, USA) for $\mathrm{p} 16^{\text {INK4a }}$.

\section{Immunofluorescence}

Embryos were fixed and permeabilized as described previously [11]. The embryos were incubated with an anti-p16 ${ }^{\text {INK4a }}$ antibody (Santa Cruz Biotechnology) diluted 1:100 in blocking solution at 4 $\mathrm{C}$ overnight and then incubated with secondary rhodamine-conjugated goat anti-rabbit IgG (Chemicon International) diluted 1:100 in $5 \%$ BSA containing PBS for $2 \mathrm{~h}$ at room temperature. The embryos were counterstained with 4,6-diamino-2-phenylindole (DAPI) to visualize the nuclei. Samples were mounted and observed under a confocal laser microscope (LSM510-V2.01, Axioplan MOT, Carl Zeiss).

\section{Statistical analyses}

The data were analyzed by the Student's $t$-test. Differences at $\mathrm{P}<0.05$ were considered to be statistically significant.

\section{Results}

\section{Expression of $R B$ in in vivo-derived mouse preimplantation embryos}

First, we examined the expression levels of endogenous RB and $\mathrm{S}$ phase-related factors during preimplantation development of in vivo-derived mouse embryos. Semiquantitative RT-PCR detected $\mathrm{RB}$ transcripts in unfertilized oocytes and that the transcript was decreased in one-cell embryos (Fig. 1A) as described previously in in vitro-derived embryos [11]. RB mRNA was not detected between 2-cell and 16-cell embryos, reappeared slightly at the morula stage and was clearly detected in blastocysts 84 and $96 \mathrm{~h}$ after hCG injection, respectively (Fig. 1A). Cyclin E mRNA was first detected in two-cell embryos in concert with the disappearance of $R B$ mRNA and appeared thereafter, although E2F1 mRNA was detected throughout preimplantation development (Fig. 1A). The $\mathrm{RB}$ expression pattern was also examined at a protein level by immunoblotting. The band at approximately $105 \mathrm{kDa}$ in unfertilized oocytes was decreased in one-cell embryos, disappeared from two-cell embryos up to morulae and then reappeared in blastocysts (Fig. 1B), confirming the results obtained by RT-PCR. 


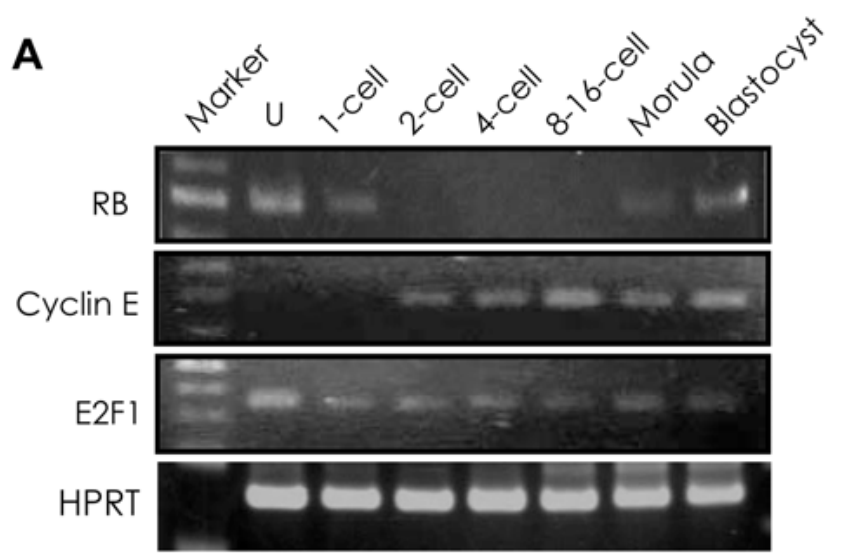

B

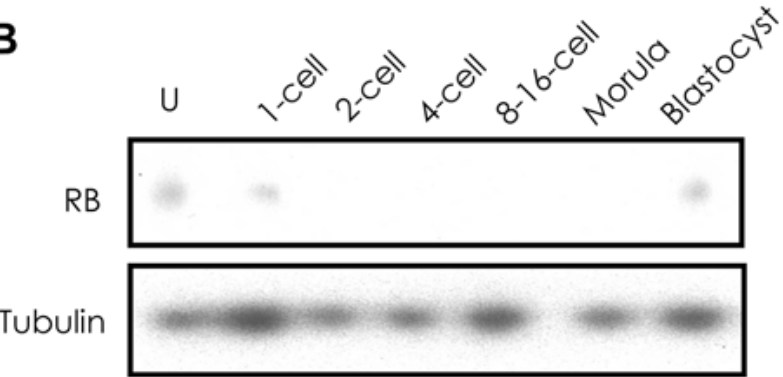

Fig. 1. Expression of $\mathrm{RB}$ in in vivo-derived mouse preimplantation embryos. A: Semiquantitative RT-PCR products amplified from the total RNA extracted from 50 unfertilized oocytes (U) or from 50 embryos at the indicated stages. $R B, E 2 F 1$, cyclin $E$ and $H P R T$ cDNAs were amplified using the specific primers shown in Table 1. B: Groups of 100 unfertilized oocytes (U) or embryos at the indicated stages were collected and subjected to immunoblotting with an anti-RB antibody or a tubulin antibody as a loading control. Different parts of the same membrane were used.

\section{Effects of $p 16^{I N K 4 a}$ on NIH3T3 cells}

In this experiment, the EGFP expression vector was cotransfected with the p16 ${ }^{\text {INK4a }}$ expression vector into NIH3T3 cells as an indicator of successful transfection and cell viability with enough gene-expression activity. The morphology and EGFP expression of NIH3T3 cells transfected with $\mathrm{p} 16^{\mathrm{INK} 4 \mathrm{a}}$ and EGFP expression vectors were compared with those of the cells transfected with EGFP expression vector alone and are shown in Fig. 2A. Both cells successfully transfected and expressed EGFP illumination, and no obvious differences were detected in morphology. The expression of mRNAs from the transfected vectors was also examined by RT-PCR (Fig. 2B). The absence of the $\mathrm{p} 16^{\text {INK4a }}$ band in the nontransfected cells and the cells transfected with EGFP expression vector alone confirmed that $\mathrm{p} 16^{\mathrm{INK} 4 \mathrm{a}}$ was not expressed in proliferating NIH3T3 cells unless it was forced to express by a vector transfection. The function of $\mathrm{p} 16^{\mathrm{INK} 4 \mathrm{a}}$ on RB phosphorylation states was examined by immunoblotting. Expression of p16 ${ }^{\text {INK4a }}$ protein was confirmed only in the cells transfected with the p16 ${ }^{\text {INK4a }}$ expression vector (Fig. 2C upper panel). RB proteins were dephosphorylated in G0/G1-arrested cells and fully phosphorylated in S phase-synchronized cells (Fig. 2C middle panel). The RB molecules in $\mathrm{p} 16^{\mathrm{INK} 4 \mathrm{a}}$-expressing cells were gradually dephosphorylated as the culture period lengthened (Fig. 2C middle panel). Finally, the effect of $\mathrm{p} 16^{\mathrm{INK} 4 \mathrm{a}}$ on the proliferation of NIH3T3 cells was examined. As shown in Fig. 2D, the number of p16 $6^{\text {INK4a }}$ expressing cells, identified by EGFP illumination, was significantly lower than that of only EGFP-expressing cells when they were cultured more than $72 \mathrm{~h}$. This result apparently indicates the inhibiting effects of $\mathrm{p} 16^{\mathrm{INK} 4 \mathrm{a}}$ on cell-cycle progression.

\section{Effects of $p 16^{I N K 4 a}$ on in vitro development of mouse embryos}

For the same reason as described above, the EGFP expression vector was coinjected with the $\mathrm{p} 16^{\mathrm{INK} 4 \mathrm{a}}$ expression vector into mouse embryos. The expression of $p 16^{I N K 4 a} \mathrm{mRNA}$ in mouse embryos was examined by RT-PCR, which revealed that the normal embryos did not express $p 16^{I N K 4 a} \mathrm{mRNA}$ throughout preimplantation development (Fig. 3A right panel). In contrast, p16 ${ }^{I N K 4 a}$ mRNA was detected in the embryos injected with the p16 ${ }^{\text {INK4a }}$ expression vector from the two-cell stage up to the blastocyst stage (Fig. 3A left panel). Expression of p16 ${ }^{\text {INK4a }}$ protein was confirmed by immunocytochemistry in embryos injected with p16 $6^{\text {INK4a }}$ expression vector, although no p16 $6^{\text {INK4a }}$ signal was detected in noninjection embryos (Fig. 3B). No morphological abnormalities were observed in the $\mathrm{p} 16^{\mathrm{INK} 4 \mathrm{a}}$-expressing embryos (Fig. 3B). The development rates of the embryos injected with p16 ${ }^{\text {INK4a }}$ and EGFP expression vectors were compared with those of the noninjected embryos and embryos injected with EGFP expression vector alone and are shown in Fig. 3C. The rates of noninjected embryos were more than $80 \%$ throughout preimplantation development in the present study; this is significantly higher than those of EGFP-expressing embryos at the four-cell stage and later. It should be noted that the development rates and morphologies of the $\mathrm{p} 16^{\text {INK4a }}$ - and EGFP-expressing embryos were comparable to those in the EGFP-alone-expressing embryos throughout the culture period, indicating the differences between preimplantation embryos and somatic cells in cell cycle progression.

\section{Discussion}

Previously, we reported that the expression of RB was downregulated between the four-cell and morula stages in in vitro-derived early mouse embryos and suggested that the low RB level caused the preimplantation-embryo-specific absence of the G1 phase [11]. In the present study, this phenomenon was confirmed at first using in vivo-derived embryos, and disappearance of RB expression after the two-cell stage and reappearance at the blastocysts stage were observed in both mRNA and protein levels. E2F1 mRNA was expressed throughout preimplantation development, and expression of cyclin E mRNA, an indicator of E2F activity, was detected at the two-cell stage concomitant with the decrease in RB expression. These results well agreed with a previous report using in vitro-derived embryos [11] and verify that the previous results were not attributable to artifacts. In addition, the present results strengthen the possibility that the preimplantation-embryo-specific absence of the G1 phase is attributable to the low RB expression 

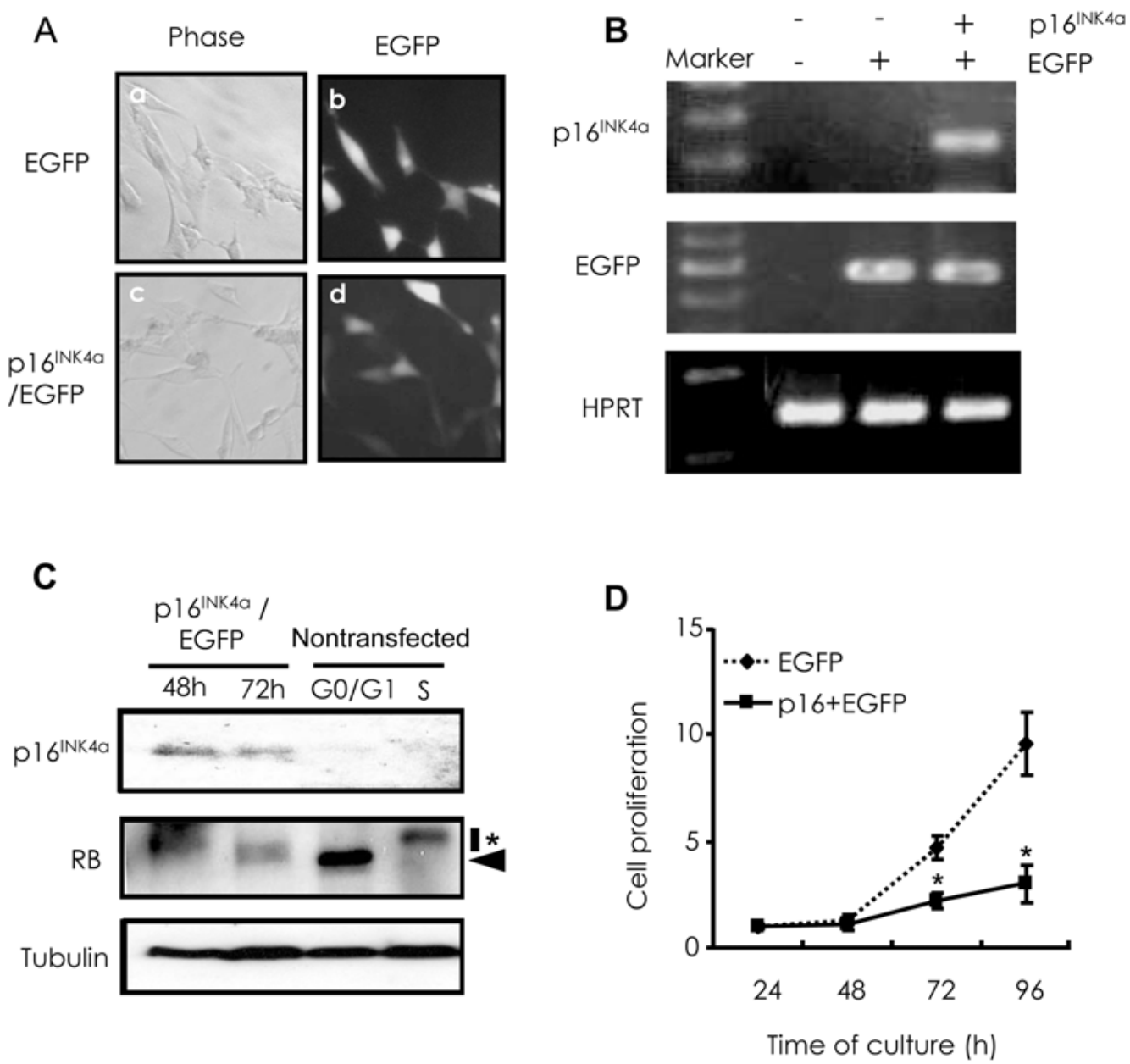

Fig. 2. Effects of p16 ${ }^{\text {INK4a }}$ on NIH3T3 cells. NIN3T3 cells were transfected with pCX-EGFP alone or pRC/CMV-p16 ${ }^{\text {INK4a }}$ with pCX-EGFP $24 \mathrm{~h}$ after the start of culture. A: The transfected cells were examined with bright field microscopy (left panels) or fluorescent microscopy (right panels) at $72 \mathrm{~h}$ after transfection. B: Expression of mRNAs was detected by RT-PCR at $48 \mathrm{~h}$ after transfection. Data of nontransfected cells are shown as a negative control. C: Expression levels of p16 ${ }^{\mathrm{INK} 4 \mathrm{a}}$ protein and RB states were examined by immunoblotting at 48 and $72 \mathrm{~h}$ after transfection. Data on nontransfected cells arrested at the G0/G1 phase or synchronized at the S phase are also shown for comparison. An arrowhead and an asterisk in the middle panel indicate dephosphorylated and phosphorylated RB, respectively. Different parts of the same membrane were used to detect RB and tubulin. D: Transfected NIH3T3 cells were collected $48 \mathrm{~h}$ after transfection and reseeded in 96-well plates for proliferation experiments. The number of EGFP-positive cells was counted at the cell adhesion point $24 \mathrm{~h}$ after reseeding, and changes in the number were expressed relative to the 24-h value. The experiments were repeated three times, and the mean \pm SEM is shown. The values with an asterisk in the p16+EGFP group are significantly lower than those in the EGFP group at the same time points.

level during preimplantation development.

Before $\mathrm{p} 16^{\mathrm{INK} 4 \mathrm{a}}$ overexpression in early mouse embryos, we confirmed the efficiency of the $\mathrm{p} 16^{\text {INK4a }}$ expression vector for inhibiting RB phosphorylation and inducing G1 arrest using a cultured cell line. Usually, RB was dephosphorylated and detected at its lowest position by immunoblotting during the cell-cyclestopped G0 phase, whereas only the upshifted band of phosphorylated RB was detected during the S phase [25], as the present study also showed. Our results revealed that the degree of RB upshift was decreased as the culture period increased after $\mathrm{p} 16^{\mathrm{INK} 4 \mathrm{a}}$ transfection, indicating the gradual RB dephosphorylation in these cells. The proliferation rate of the $\mathrm{p} 16^{\text {INK4a }} / \mathrm{EGFP}$-transfected cells was significantly lower than that of the cells transfected with EGFP alone. These results confirm that the $\mathrm{p} 16^{\mathrm{INK} 4 \mathrm{a}}$ expression vector used can inhibit RB phosphorylation and induce G1 arrest in transfected cells.

The present results in mouse embryos show that the preimplantation development rates were not different between embryos injected with both $\mathrm{p} 16^{\mathrm{INK} 4 \mathrm{a}}$ and EGFP expression vectors and those injected with EGFP expression vector alone. Although the blastocyst cell numbers were not examined in the present study, these two groups were expected to have the same values based on their identical cell cycle speeds until the 8/16-cell stage. Expression of p16 ${ }^{\text {INK4a }}$ was confirmed in EGFP-expressing embryos in the group injected with both vectors at the mRNA and protein levels. As the EGFP expression rates of these two groups were not significantly 

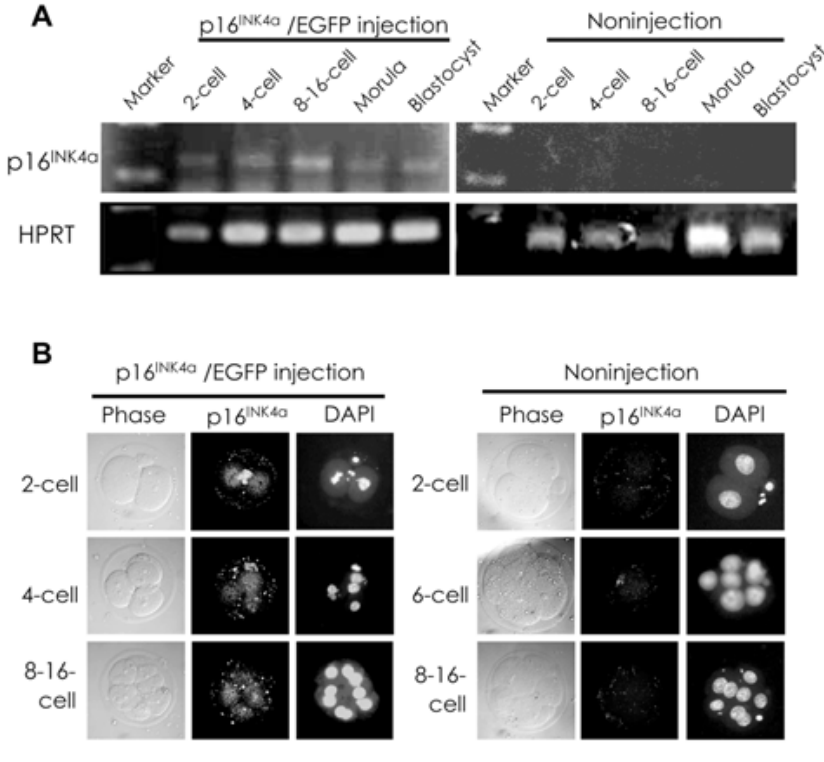

C

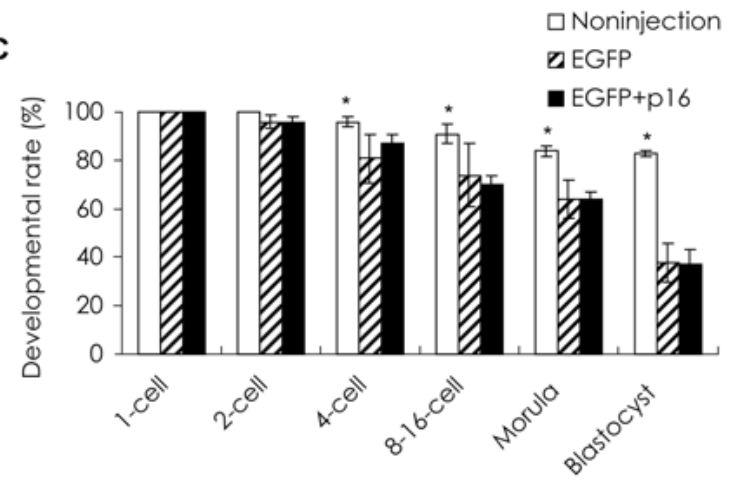

Embryo stage

Fig. 3. Effects of $\mathrm{p} 16^{\mathrm{INK} 4 \mathrm{a}}$ on in vitro development of mouse embryos. The embryos were injected with pRC/CMV-p16 ${ }^{\text {INK4a }}$ and pCXEGFP into a pronucleus and cultured up to $96 \mathrm{~h}$ after injection. A: Expression of $p 16^{I N K 4 a}$ mRNA was detected by RT-PCR at the indicated stages. HPRT mRNA is shown as a loading control. B: Expression of p16 $6^{\mathrm{INK} 4 \mathrm{a}}$ protein was examined at the indicated stages by immunocytochemistry and shown with bright field microscopy (phase) and nuclear staining (DAPI). C: Development states were examined as described in Materials and Methods, and only EGFP-positive embryos were used for the calculation of development rates. The rates were expressed as percentages of the number of all EGFP-positive embryos in the EGFP and EGFP + p16 groups and the number of one-cell embryos in the noninjection group. The experiments were repeated three times, and the mean \pm SEM is shown. Asterisks indicate values significantly different from those of the EGFP group at the same stages.

different, these two groups should have the same viabilities and gene expression activities. The data clearly show that $\mathrm{p} 16^{\mathrm{INK} 4 \mathrm{a}}$ expression could not stop the cell cycle of early mouse embryos and had no effect on preimplantation development. The low preimplantation development rates of injected embryos compared with noninjected embryos might be attributable to the injection stress
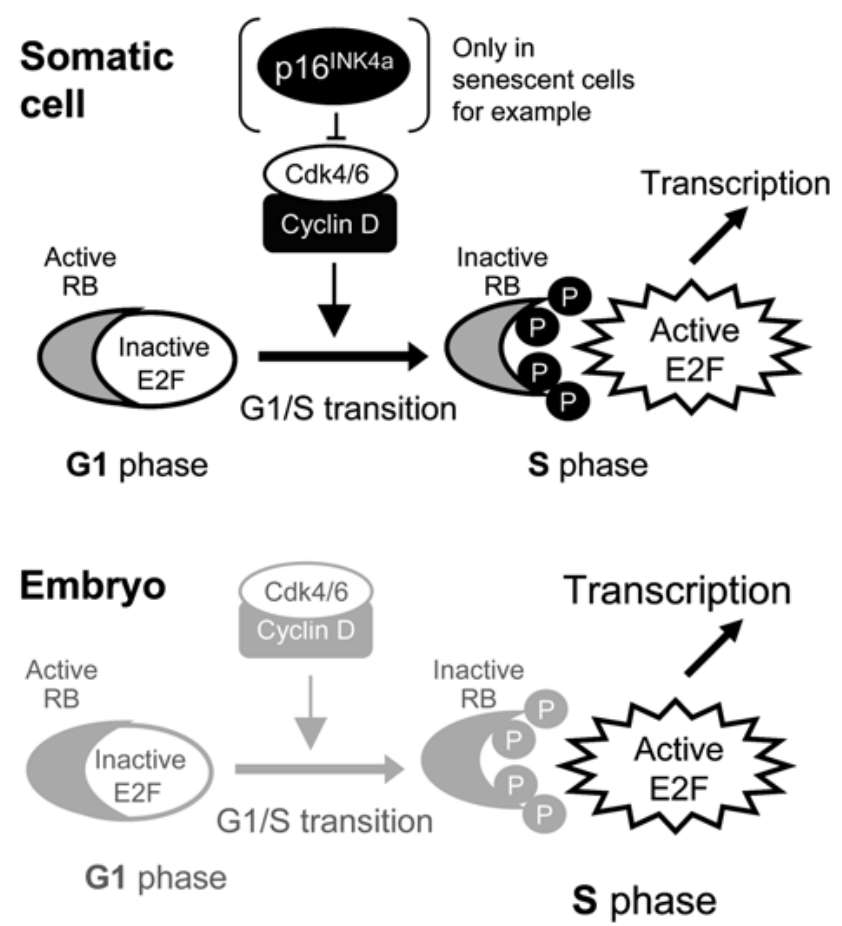

Fig. 4. Schematic diagram of the mechanisms for G1/S transition in somatic cells and for absence of the G1 phase in embryos.

and deteriorative effects of EGFP [26]. The present results suggest that RB phosphorylation is not important for the preimplantationembryo-specific absence of the G1 phase and that the low RB level itself is attributable to this phenomenon.

The present study is the first to induce $\mathrm{p} 16^{\text {INK4a }}$ overexpression in preimplantation mammalian embryos and thus may be of high biological importance. In cultured cells, p16 ${ }^{\text {INK4a }}$ works as a potent cancer suppressor gene by induction of cellular senescence in the overexpressed cells [27]. It has been well known that the phosphorylation state of $\mathrm{RB}$, but not the protein level, is important for the regulation of $\mathrm{RB}$ function in somatic cells $[28,29]$ and that $\mathrm{RB}$ expression never disappears in somatic cells, except for cancer cells $[17,18]$. If the G1/S transition of embryos is regulated by the same mechanism that regulates somatic cells, inhibition of RB phosphorylation must result in cell cycle arrest in the embryos. The failure of cell cycle arrest despite $\mathrm{p} 16^{\mathrm{INK} 4 \mathrm{a}}$ overexpression strongly indicates that early mouse embryos are regulated by a specific cell cycle, which is similar to that of cancer cells and different from that of normal somatic cells. A shortened cell cycle, serum independence and decrease in cell volume have been observed in some cancer cells as a result of the expression of adenovirus E1A or papillomavirus E7, either of which binds with RB and prevents RB from interacting with E2F [28, 30]. These changes observed in RB-inactivated cancer cells closely resemble the characteristics shown in preimplantation embryos, supporting the similarity of cell cycle regulation in early embryos and cancer cells.

$\mathrm{RB}$ knockout is lethal in mouse embryos just prior to birth as a results of defects in neurogenesis and hematopoiesis, but RB 
knockout mice have no detectable morphological abnormalities [31-33], and the double-knockout mice of RB and p107 or p130, which are both similar to $\mathrm{RB}$, can survive until 13 days postcoitus $[34,35]$. These facts indicate the dispensability of RB-dependent cell-cycle arrest during early embryo development. In addition, double-knockout mice of CDK4 and CDK6 and the triple-knockout mice of cyclins D1, D2 and D3 have been generated and shown to have no detectable morphological abnormalities, although they do die after 15.5 days postcoitus as a result of hematological disorder $[36,37]$. These facts indicate that the phosphorylation factors present upstream from RB are not essential in early mouse embryos and support the present opinion postulating the importance of low $\mathrm{RB}$ levels for the preimplantation-embryo-specific absence of the G1 phase.

Despite the presence of endogenous RB until the two-cell stage of mouse embryos, $\mathrm{p} 16^{\mathrm{INK} 4 \mathrm{a}}$ expression could not arrest the cell cycle before this stage in the present study. It has been reported that transcriptional inhibition has no effect on the development of mouse embryos until the two-cell stage [38] because maternal factors accumulate in mouse embryos until zygotic gene activation (ZGA), which occurs at the two-cell stage, and the cell-cycle progression is regulated without transcription [39-41]. Our present results consolidate the general explanation for the absence of the G1 phase in Xenopus and invertebrate embryos, which have a large number of maternal factors during cleavage; this is also the case in mouse embryos before ZGA.

In summary, our results suggest that the cell cycle of preimplantation mouse embryos substantially lacks the G1-phase because of the decrease in RB expression itself after ZGA, but not because of the phosphorylation of $\mathrm{RB}$, and that the decrease in $\mathrm{RB}$ expression results in the constitutive E2F activation and continuous transcription of factors required for $\mathrm{S}$ phase entrance, such as cyclin $\mathrm{E}$ (Fig. 4). Moreover, the present study provides potent proof that preimplantation-embryo-specific cell cycle regulation is similar to that of cancer cells.

\section{Acknowledgments}

We are grateful to Dr J Zalvide, Dr M Wervo, Dr M Okabe and Dr J Miyazaki for generous gift of vectors used in the present study. This research was supported by a Grant-in-Aid for Scientific Research (no. 22380147 to KN) from the Japan Society for the Promotion of Science.

\section{References}

1. Moore GD, Ayabe T, Kopf GS, Schultz RM. Temporal patterns of gene expression of G1-S cyclins and cdks during the first and second mitotic cell cycles in mouse embryos. Mol Reprod Dev 1996; 45: 264-275.

2. Smith RK, Johnson MH. Analysis of the third and fourth cell cycles of mouse early development. J Reprod Fertil 1986; 76: 393-399.

3. Chisholm JC. Analysis of the fifth cell cycle of mouse development. J Reprod Fertil 1988; 84: 29-36.

4. Nevins JR. Toward an understanding of the functional complexity of the E2F and retinoblastoma families. Cell Growht Differ 1998; 9: 585-593.

5. Dyson N. The regulation of E2F by pRB-family proteins. Genes Dev 1998; 2: 2245-2262.

6. Weintraub SJ, Prater CA, Dean DC. Retinoblastoma protein switches the E2F site from positive to negative element. Nature 1992; 358: 259-261.

7. Chellappan SP, Hiebert S, Mudryj M, Horowitz JM, Nevins JR. The E2F transcrip- tion factor is a cellular target for the RB protein. Cell 1991; 65: 1053-1061.

8. Hiebert SW, Chellappan SP, Horowitz JM, Nevins JR. The interaction of RB with E2F coincides with an inhibition of the transcriptional activity of E2F. Genes Dev 1992; 6: 177-185.

9. Ewen ME, Sluss HK, Sherr CJ, Matsushime H, Kato J, Livingston DM. Functional interactions of the retinoblastoma protein with mammalian D-type cyclins. Cell 1993; 73: 487-497.

10. Kato J, Matsushime H, Hiebert SW, Ewen ME, Sherr CJ. Direct binding of cyclin D to the retinoblastoma gene product $(\mathrm{pRb})$ and $\mathrm{pRb}$ phosphorylation by the cyclin $\mathrm{D}$ dependent kinase CDK4. Genes Dev 1993;7:331-342.

11. Iwamori N, Naito K, Sugiura K, Tojo H. Preimplantation-embryo-specific cell cycle regulation is attributed to the low expression level of retinoblastoma protein. FEBS Lett 2002; 526: 119-123.

12. Xie Y, Sun T, Wang QT, Wang Y, Wang F, Puscheck E, Rappolee DA. Acquisition of essential somatic cell cycle regulatory protein expression and implied activity occurs at the second to third cell division in mouse preimplantation embryos. FEBS Lett 2005; 579: 398-408.

13. Russo AA, Tong L, Lee JO, Jeffrey PD, Pavletich NP. Structural basis for inhibition of the cyclin-dependent kinase Cdk6 by the tumour suppressor p16 ${ }^{\text {INK4a }}$. Nature 1998 395: 237-243

14. Serrano M, Hannon GJ, Beach D. A new regulatory motif in cell-cycle control causing specific inhibition of cyclin D/CDK4. Nature 1993; 366: 704-707.

15. Lukas J, Parry D, Aagaard L, Mann DJ, Bartkova J, Strauss M, Peters G, Bartek J. Retinoblastoma-protein-dependent cell-cycle inhibition by the tumour suppressor p16. Nature 1995; 375: 503-506.

16. Hara E, Smith R, Parry D, Tahara H, Stone S, Peters G. Regulation of p16CDKN2 expression and its implications for cell immortalization and senescence. Mol Cell Biol 1996; 16: 859-867.

17. Qin XQ, Livingston DM, Kaelin WG Jr, Adams PD. Deregulated transcription factor E2F-1 expression leads to S-phase entry and p53-mediated apoptosis. Proc Natl Acad Sci USA 1994; 91: 10918-10922.

18. Takahashi R, Hashimoto T, Xu HJ, Hu SX, Matsui T, Miki T, Bigo-Marshall H, Aaronson SA, Benedict WF. The retinoblastoma gene functions as a growth and tumor suppressor in human bladder carcinoma cells. Proc Natl Acad Sci USA 1991; 88: $5257-5261$

19. Quinn P, Kerin JF, Warnes GM. Improved pregnancy rate in human in vitro fertilization with the use of a medium based on the composition of human tubal fluid. Fertil Steril 1985; 44: 493-498.

20. Lawitts JA, Biggers JD. Culture of preimplantation embryos. Method Enzymol 1993; 225: 153-164.

21. Lam EW, Morris JD, Davies R, Crook T, Watson RJ, Vousden KH. HPV16 E7 oncoprotein deregulates B-myb expression: correlation with targeting of p107/E2F complexes. EMBO J 1994; 13: 871-878.

22. Kashima K, Kano K, Naito K. Mos and the mitogen-activated protein kinase do not show cytostatic factor activity in early mouse embryos. J Reprod Dev 2007; 53: 1175 1182.

23. Laemmli UK. Cleavage of structural proteins during the assembly of the head of bacteriophage T4. Nature 1970; 227: 680-685.

24. Nishimura Y, Kano K, Naito K. Porcine CPEB1 is involved in Cyclin B translation and meiotic resumption in porcine oocytes. Anim Sci J 2010; 81: 444-452.

25. DeCaprio JA, Furukawa Y, Ajchenbaum F, Griffin JD, Livingston DM. The retinoblastoma-susceptibility gene product becomes phosphorylated in multiple stages during cell cycle entry and progression. Proc Natl Acad Sci USA 1992; 89: 1795-1798.

26. Liu HS, Jan MS, Chou CK, Chen PH, Ke NJ. Is green fluorescent protein toxic to the living cells? Biochem Biophys Res Commun 1999; 260: 712-717.

27. Kato D, Miyazawa K, Ruas M, Starborg M, Wada I, Oka T, Sakai T, Peters G, Hara E. Features of replicative senescence induced by direct addition of antennapediap16INK4A fusion protein to human diploid fibroblasts. FEBS Lett 1998; 427: 203-208.

28. Weinberg RA. The retinoblastoma protein and cell cycle control. Cell 1995; 81: 323 330

29. Sherr CJ. Cancer cell cycle. Science 1996; 274: 1672-1677.

30. Taya Y. RB kinases and RB-binding proteins: new points of view. Trends Biochem Sci 1997; 22: 14-17

31. Clarke AR, Maandag ER, van Roon M, van der Lugt NM, van der Valk M, Hooper ML, Berns A, te Riele H. Requirement for a functional Rb-1 gene in murine development. Nature 1992; 359: 328-330.

32. Jacks T, Fazeli A, Schmitt EM, Bronson RT, Goodell MA, Weinberg RA. Effects of an $\mathrm{Rb}$ mutation in the mouse. Nature 1992; 359: 295-300.

33. Lee EY, Chang CY, Hu N, Wang YC, Lai CC, Herrup K, Lee WH, Bradley A. Mice deficient for $\mathrm{Rb}$ are nonviable and show defects in neurogenesis and haematopoiesis. Nature 1992; 59: 288-294.

34. Lee MH, Williams BO, Mulligan G, Mukai S, Bronson RT, Dyson N, Harlow E, 
Jacks T. Targeted disruption of p107: functional overlap between p107 and Rb. Genes Dev 1996; 10: 1621-1632.

35. Sage J, Mulligan GJ, Attardi LD, Miller A, Chen S, Williams B, Theodorou E, Jacks T. Targeted disruption of the three Rb-related genes leads to loss of $\mathrm{G}(1)$ control and immortalization. Genes Dev 2000; 14: 3037-3050.

36. Kozar K, Ciemerych MA, Rebel VI, Shigematsu H, Zagozdzon A, Sicinska E, Geng Y, Yu Q, Bhattacharya S, Bronson RT, Akashi K, Sicinski P. Mouse development and cell proliferation in the absence of D-cyclins. Cell 2004; 118: 477-491.

37. Malumbres M, Sotillo R, Santamaría D, Galán J, Cerezo A, Ortega S, Dubus P, Barbacid M. Mammalian cells cycle without the D-type cyclin-dependent kinases Cdk4 and Cdk6. Cell 2004; 118: 493-504.

38. Rambhatla L, Latham KE. Strain-specific progression of alpha-amanitin-treated mouse embryos beyond the two-cell stage. Mol Reprod Dev 1995; 41: 16-19.

39. Shultz RM. Regulation of zygotic gene activation in the mouse. Bioseeays 1993; 5: 531538.

40. Wiekowski M, Miranda M, DePamphilis ML. Requirements for promoter activity in mouse oocytes and embryos distinguish paternal pronuclei from maternal and zygotic nuclei. Dev Biol 1993; 159: 366-378.

41. Forlani S, Nicolas JF. Quantification of minute levels of beta galactosidase in individual 2- to 16-cell-stage mouse embryos. Trends Genet 1996; 12: 498-500. 